\title{
Language as a Second Skin: The Representation of Black Africans in Portuguese Theatre (Fifteenth to Early-Seventeenth Century)*
}

\author{
ANDRÉ BELO \\ Université de Rennes 2, France
}

Cet article analyse le langage et le personnage de l'Africain Noir dans le théâtre portugais du XVI siècle, en particulier dans les pièces ou autos de Gil Vicente et d'António Ribeiro Chiado, ainsi que celles d'autres auteurs moins connus et quelques intermèdes espagnols. On accompagne l'évolution du stéreotype du Noir considéré incapable de parler correctement les langues ibériques, depuis sa première apparition littéraire, dans le Cancioneiro Geral de Garcia de Resende. La première partie de cet article, plus méthodologique, met en cause la possibilité d'utiliser le langage attribué aux Noirs pour reconstituer une langue orale effectivement parlée, l'intention de dénigrement étant constitutive de ce discours. Ensuite, en parcourant les différentes pièces, on propose la notion d'un langage presque phénotypique, qui " colle à la peau » des Noirs et les désigne même lorsqu’ils ne sont pas sur scène. De manière moins rigide que le stéréotype, cette "seconde peau ", qui est la langue, devient un instrument de dénigrement en soi, y compris de certains personnages blancs.

\section{Preliminary methodological remarks}

n image of black Africans in the expanding Iberian society of the fifteenth
ond sixteenth centuries was being rapidly and effectively forged by writers
ated use of the inappropriately called lingua de preto or habla de negros ("black's
language" or "black's speech"), a literary tool that consisted of the parodic rep-
resentation of a black African's speech, derived from Portuguese or Spanish
but including systematic deformations both in grammar and phonetics. This 
parodic form of speech was first popularized in dances and plays presented specially at royal feasts. It also circulated as text, theatrical or otherwise, in manuscript or printed form, from the facetious academic poem to the pamphlet. It was diffused in a variety of media and social spaces, from the royal palace to corrales or pátios de comedias, from street performances to academic circles. In eighteenth-century Portugal, alongside theatrical performances in entremeses - a tradition that lasted until the teatro de revista (revues), well into the twentieth century-we observe a proliferation of printed objects that specialized in the parody of black people's speech, particularly in the form of almanacs (prognósticos and lunários). ${ }^{1}$

Scholarly interest in this phenomenon is not new, but only recently has this particular aspect of literary production been integrated in a wider reflection on the stereotyping of racial difference and, more broadly, on the social and cultural consequences of the presence of Sub-Saharan populations in Europe. ${ }^{2}$ The scarcity of studies in scholarly traditions such as that of Spain, where the historical presence of black communities was very important, has also been noticed, ${ }^{3}$ and the same may be said for Portugal. Long-lasting cultural reasons can be invoked to explain this relative lack of interest. In the particular case of Portugal, we can invoke the widespread persistence, well beyond the fall of the dictatorship in 1974, of "Lusotropicalism," the colonial ideology inspired by Gilberto Freyre's works which stated that racial relations within the Portuguese Empire were intrinsically benign and marked by a spirit of universal humanism. ${ }^{4}$ One particular manifestation of this ideological bias can be found precisely in the way, until recently, Portuguese and also Spanish scholars accepted the use-without discussion-of the expression lingua de preto or its several variants (fala or habla de negros, língua boçal/bozal, língua de Guiné, meia-língua, etc.). The adjective preto in particular, which was not present in the earlier Portuguese texts, cannot be used today without acknowledging the strong racist connotation it acquired in nineteenth- and twentieth-century colonial Portugal. By importing or adapting these words from early modern texts without criticism, scholars helped maintain the symbolic violence that was inherent in the use of such a speech: it was a language made by white authors, destined to be heard and/or read by a public dominated by white people, and with an intention of mockery, expressing a strong social and racial prejudice. The fala de negros - with its implicit idea that one whole group of individuals, defined by their physical appearance and regardless of their different origins 
and life experiences, would speak the same Iberian-derived language-was in reality a caricature; a denigrating, manufactured language.

An extract from a so-called interlude or dialogue called Los Mirones, sometimes attributed to Miguel de Cervantes, might serve here as an illustration of the symbolic violence I am referring to. Set in Seville, the dialogue presents the leisurely conversations of two gentlemen and a university graduate (licenciado). The latter informs his interlocutors of a project, conceived by his students, of regularly collecting tasty and extravagant anecdotes ("que tienen más del gustoso y del extravagante") in the popular quarters of the city. Disguised and separated in groups of two, "like monks" ("como frailes") but in the position of voyeurs ("mirones"), the students bring back to their mentor stories that mock the urban humble classes: slaves, ordinary women, involuntarily comic blind people. The first anecdote that the licenciado narrates to his friends, reported by one of the mirones, would have occurred in the small plaza of the church of Santa María la Blanca. In this place, where an "infinity of black men and women" ("infinidad de negros y negras") frequently gathered,

A student arrived under concealment to [a place] where he saw some [black people] in good conversation. After many compliments between them (for they are full of courtesy and ceremonies, not only with white people, but also between themselves), one of them asked another in his half-language: "Sir, please tell me, is it true that your master has sold you?" - "Yes, Sir, he has sold me indeed," said the other. - "And for how much, good grief, did he sell you?". - "For one hundred and twenty ducados." The other, bending his head, and looking at him from head to toe, said with great pondering: - "It is too much, good grief! You are not by no means worth it: you are worth 80 ducados, and not a penny more."

While the situation reported here pretends to be spontaneous and even objective (the student remains unnoticed while he listens to the conversation; he is supposedly an impartial witness), the text works precisely in the opposite way, conveying a set of interconnected prejudices. The situation is presented entirely according to the fantasy of the student. First, the supposed ceremonious character of black people is an element of a condescending stereotype that elevates them to an "exotic" state. Then, a (learned) white intermediary is 
necessary to reproduce the dialogue-without having to certify its authenticity. In itself, the conversation among the black people, in their "half language" ("media lengua"), does not convey any kind of autonomy. The student alone has the key to understanding their speech, and he keeps that key to himself. The scene is marked by a high degree of symbolic violence, where the speech, instantaneously "translated," conveys a brutal assimilation of servitude by its victims: left alone, unwatched by white people, black people evaluate themselves as slaves, and even downgrade their own value as merchandise.

This particular anecdote documents a form of symbolic violence that, I believe, is at the root of the denigrating language. If such is the case, then we must rethink the methodology that allows the use of dramatic texts as sources in the study of speech in black communities. In fact, the lack of other sources has led several authors to attempt to describe European-based pidgins, from Edmund de Chasca (1946) to Paul Teyssier (1959) or, more recently, Baranda Letuario (1989) and John Lipski (1994). ${ }^{6}$ Although most or all of these authors recognize that the "recorded" speech of black characters is a questionable linguistic source, none of them sees a major obstacle to its use in the study of real speech in black communities.

Yet two major objections can be presented. The first has to do with the incompatibility between a literary device that is used to obtain comic effects and the accuracy needed to transcribe a living language. For the parody to work (as it can only through recognition) the parodic speech must be perceived, to some extent, as real-but we have no accurate way of separating the imitation of real speech from the stereotype. What we do know is that accurate transcription was not the primary goal here. Oral or written, it was an artificial language that served literary communication between white people only. This "half-language" (meia-língua, or media língua) or "mimic language" (arremedo de lingua), as it was called by the very authors who used it, lacked the dignity and status of a full language; yet it has been purported to be a record.

To answer this objection, one could say that a notable stability seems to characterize this particular literary expression. Written by different authors over a long period, such texts might be shown to have important features of grammar and phonetics in common, which would allow us to identify regularities that, moreover, would be consistent with today's surviving Afro-Portuguese Creoles. This would constitute evidence of an independent stable reality which the mediation of stereotype and caricature could not invalidate. ${ }^{7}$ But even if we 
allow for such evidence, it can hardly prove the stability of past Afro-Iberian real speech. It may be more helpful to reverse the question: Aren't the artificial linguistic features that we see in literary texts by Portuguese and Spanish writers in fact creating the regularities of the language? Fixedness, one could argue, is produced by the written production of the language, inducing literal copy and simplified reproduction in subsequent representations and texts. Again, parodic language has to be well understood or at least automatically identified by the audience. Essentially derived from a European base, the "black speech" of the dramatists had to present regularities that could be easily recognized. Consequently, as Paul Teyssier has noticed, common nouns of African origin were generally absent from this form of language. ${ }^{8}$ Expressive and stylistic reasons seem to have prevailed over linguistic considerations when making black characters speak. ${ }^{9}$

A second methodological objection has a wider scope, inviting prudence in the analysis of all written transcriptions-not only literary-of oral speech. Textual stability cannot be taken for granted. In recent decades, early modern cultural historiography has pointed out the very active role that diverse intermediaries, and not only the authors, played in the editing of handwritten and printed texts. For instance, widely observed practices of sixteenth-century proof correction during the printing process account for the existence of variants within a single edition. One example comes from arguably the earliest record of denigrating language: the late fifteenth-century poem composed by Fernão da Silveira, printed in 1516 in the Cancioneiro Geral by Garcia de Resende. According to the philological notes made by Carolina Michaëlis de Vasconcelos, this poem has different versions in the surviving copies of Resende's compilation, presenting several important lexical variations. ${ }^{10}$ Printing house practices, including involuntary faults or a misinterpretation of earlier texts, can explain the existence of variations in the way of writing words from one edition to the other. The speech of the black character in Fragoa d'Amor, in two different editions of Gil Vicente's posthumous compilation of plays, the Copilaçam... (1562 and 1586), presents very few divergences, but includes at least two significant phonetic alterations. ${ }^{11}$ In a later period-the middle of the eighteenth century - and a different medium, we find two different handwritten copies of one poem in parodic black language by António de Brito e Oliveira. Published side by side, they show us a wide range of variations, including some of those "regular" deformations that seem to constitute the basis of the stability of this 
speech: the substitution of " $r$ " by " 1 "; the weakness of ending consonants; the (dis)agreement in gender and number. ${ }^{12}$

These examples lead us to the possibility that the always complex game of stability and variation in speech depended more, in this particular case, on the logic of transmitting written text than on the imitation of oral speech. We possess several other testimonies that point to the conventional, scholarly features of denigrating language. I will here sort them into three types:

1. The existence of instructions on how to write fala de negro. A well-known example is Francisco de Quevedo's statement in his Libro de todas las cosas (1631): 'If you are a comedy author and a poet, you will know guineo by changing $r r$ into $l l$ and in reverse: like Francisco, Flancico; primo, plimo." Quevedo's simplified rule appears in a section called "[Advice] to know the whole of sciences and mechanical and liberal arts in one day." ${ }^{13}$ Even though we read this instruction as irony, rather than practical advice to be followed literally, it remains a credible example of the sort of written rules that comedy authors adopted, and of the inspiration they found in available written dialogues. Besides guineo, Quevedo gives rules for the construction of dialogues in the following languages: "Vizcaíno" (language from Biscay), "Morisco" ("Moorish"), French, Italian, German and Flemish, Arabic, Greek and Hebrew.

2. The existence of specialists in the writing of denigrating language. Such, at least, was the case for the aforementioned António de Brito e Oliveira, born in Salvador, Bahia, and active as secretary for academies in Lisbon in the mid-eighteenth century. The handwritten copies of his poetry for the Academia dos Ocultos, published by Ana Hatherly, present him as someone who was an expert in lingua de preto in two different documents. ${ }^{14}$ For an earlier period, testimony of such an expertise also exists, but it concerns acting and the mimicry of the manner of speaking. We can quote the well-known example, referred to by Cervantes, of how Lope de Rueda excelled in the interpretation of some minor characters, like the one of the black woman. ${ }^{15}$

3. Finally, the existence of a "contamination" between the different stereotyped languages that appear in Iberian plays, showing us how "new" parodic languages depended upon those that already existed and could have a similar satiric function. In the plays of Jaime de Guëte and Juan Pastor, 
for instance, black people speak a blend of Portuguese-based words and the phonetics attributed to Moors, such as xexeo (lisp; in Portuguese, ciciar). ${ }^{16}$ As suggested by Fernão da Silveira's poem, composed to accompany a dance described as "Moorish," the same cross-over may have taken place in the names attributed to music and dances performed by black people.

In the following pages I will analyze the way the "character" of the black African was popularized in sixteenth-century Portuguese theatre through the use of parodic language. I will try to describe a set of rigid stereotypes, but also the way in which these same stereotypes became available for a theatrical repertoire of social mockery which could include a ritualized, localized inversion of the social order. The corpus of my research is comprised of eleven Portuguese Autos and Práticas from the sixteenth century, mostly by Vicente and António Ribeiro Chiado, along with three earlier dramatized texts from the Cancioneiro Geral by Garcia de Resende (1516). ${ }^{17}$ I will also bring into my presentation some examples of early seventeenth-century Spanish interludes (entremezes), because their treatment of language and character has evident affinities with earlier Portuguese texts.

Fra Molinero has shown how, between the sixteenth and seventeenth centuries in Spanish comedy, an important evolution took place in the treatment of black characters - with the appearance of the first "serious black characters" ("negros graves"), as opposed to comic ones, which were relegated to minor genres such as entremeses. Black protagonists of comedies appear to represent the exceptional destiny of saints (El Prodigio de Etiopia; El Santo Negro Rosambuco, both by Lope de Vega), men of letters (Juan Latino, by Ximenez de Enciso), or brave warriors (El Valiente Negro en Flandres, by Andrés de Claramonte). In these plays, the black character speaks a "correct" Spanish and is developed to a certain degree of individuation and moral conflict, although, as Fra Molinero has also shown, it remains indebted to the dominant stereotype. ${ }^{18}$ In Portuguese theatre, even though it remained dependent on Spanish repertoire and companies during the seventeenth and part of the eighteenth centuries, a similar evolution did not took place. 


\section{2. "Mourisca Retorta"}

A poem in two octaves composed to be sung or recited to accompany a Moorish dance (mourisca retorta), composed by Fernão da Silveira, a high officer of the royal house of King João II of Portugal, is arguably the first known example of parodic black "language" in Iberian texts. It presents the tribute of a black king from Sierra Leone to a western monarch and his daughter (or, as we shall see, daughter-in-law), who had commissioned the poem, on the occasion of her wedding. The text was dated from 1455 by nineteenth-century Portuguese scholars, and thought to have been performed at the festivities for Princess Joana's marriage to Henry IV of Castile. However, it is impossible to sustain such a chronology today. The poem mentions an African toponym, Sierra Leone, which was not used before the 1460s, when the Portuguese baptized the cape. The date of the poem must be later. Using the description made by the royal chronicler Garcia de Resende of the wedding feasts of Princess Isabella of Castile and Prince Afonso of Portugal, in Évora at the end of the year 1490, José da Silva Terra gave strong arguments to a new dating of the "Mourisca Retorta." ${ }^{19}$ Garcia de Resende's detailed description of the wedding mentions a "representation of a king of Guinea" and a "very big and rich Mourisca retorta." Garcia de Resende was also the compiler of the Cancioneiro Geral, the work in which the poem was later printed in 1516; he refers, in different sources, to the central role of Fernão da Silveira, author of the poem, both in the festivities and, before that, in the preparation of the wedding, having been sent as an ambassador by the Portuguese king to Seville to organize the matrimony at the beginning of $1490 .{ }^{20}$ We have here a strong accumulation of hints that all point in the same direction: the mourisca retorta, along with the poem, was probably performed during the above-mentioned feasts at the end of November of 1490 . The deference shown in the poem to the "father" of the Castilian princess can still be interpreted as an homage to the king of Portugal, host of the feasts, if we understand this as a form of treatment underlining the affection between the bride and her future father(-in-law). ${ }^{21}$

Garcia de Resende's account insists on the richness and dimension of the performance, composed of hundreds of black dancers and giant puppets. The physical appearance of the dancers, including noisy accessories and costly decorations, is emphasized: 
There was a very big representation of a King of Guinea, with three amazing Giants that looked alive and had almost 30 feet each. They were richly dressed, painted in gold, and everything looked very rich. And with them [there was] a very big and rich mourisca retorta, with 200 black coloured men, very good dancers, all full of thick shackles over their golden arms and legs. And [they were] very well ordered, a very perfect thing, and highly expensive because they were so many. [And there was] a great deal of expenses in silk and gold and they made such a noise with the little bells [that] they wore that one could not hear them. ${ }^{22}$

As for the poem, it assumes the voice of a king of Sierra Leone addressing the princess:

Me king of blacks [coming] from Sierra Leone the country where we live [is] very far "Tubao" came in a caravel from Lisbon He told [us] many news from [your] wedding Me want [to] see you at once, how you are leave my wife sail very quickly because we always serve your father black [is] very happy [that] you are queen

This people [of] mine very good. In our country [we] never play, always fight [we] don't know what to dance [in] your country [we] dance in the way of our country If you want me [to] come [I] will do what [I] know take what I find Prepare good place, God bless you And at once mine black, milady, [will] dance. ${ }^{23}$

These verses convey a set of attitudes regarding language, power, and morality. As to language, we see a grammatical simplification (absence of verbal conjugation and prepositions, use of a mim instead of $e u$ as the personal pronoun) of Portuguese. Interestingly, phonetic deformation and discord in gender, both characteristic of later texts, are almost absent here, with the possible 
exception of two aphereses (synha for asinha, quy for aqui). From a political and moral point of view, two important ideas about the black African's relationship with western society are expressed here: although a monarch himself, the African king is eager to serve and pay tribute to the European monarch; this tribute "spontaneously" assumes a form of entertainment (dance) and asserts the Africans' structural incapacity to make peace in internal affairs.

\section{Some considerations on stereotypes}

These and other forms of ideological categorizing of black Africans are present in sixteenth-century dramatic texts, where a repetition of images and situations combined to form a stereotype. Stereotyped identification of characters in theatre was produced through the use of accessories such as costumes, makeup and masks, and everything else that was relevant to describe the character: name, voice, language, gestures, behaviour, and all the accompanying objects. These had metonymic properties, signifying moral behaviour and social rank. To be sure, strong stereotyping was not exclusive to black characters. With different moral connotations, the same kind of identification-including the use of linguistic features - can be made in the case of the "character" of Moors, Jews, Gypsies, peasants, or women of the people. What seems to be specific to black characters is the central role of the colour of the skin in the crystallization of associations. Whether male or female, doing the housework, or working outside at the service of a master, the black character is often identified by the mere designation "black man" or "black woman." As I will try to demonstrate, linguistic distortion, even when black characters happen to speak a "correct" language, also becomes inseparable from the character, working very often as a signifier like the colour of skin.

Associated with colour of skin and linguistic incompetence were social inferiority and servitude. As the poem quoted above shows, although dominant in Portuguese fifteenth- and sixteenth-century texts, the identification between black characters and the condition of slavery was not always immediate. In a universe of eleven texts, four characters are not slaves: there are two African kings ("Mourisca Retorta," 1490; Vicente, Nau d'Amores, 1527), a musician (Chiado, Auto da Natural Invenção, mid-sixteenth century) and a physician (Auto de Vicenteanes Joeira, printed in 1574). Still, a "natural" association of 
blacks with slavery is present even when black characters are not slaves. The evocation of the black people's condition becomes a proverbial synonym of servitude. The valet's monologue that opens António Ribeiro Chiado's Prática de Oito Figuras, a complaint about courtly life, compares it with slavery: "We serve like blacks from Guinea" ("Servis / como negros de Guiné"). When free, the black character has a social status above the expectations of both the other characters and the audience. Threats of reduction to the condition of slave occur through insults and references to physical punishments often reserved for slaves, like the act of pouring boiling animal fat onto skin. The Auto da Natural Invenção, by Chiado, shows a typical case of this degrading expectation. A landlord (dono da casa) who had ordered an auto to be played in his house asks a black man, whom he takes to be a slave, to stand up because his chair was needed for the play. After insulting him and threatening him with punishment, he hears, to his astonishment, that the black man participates in the representation as a talented guitar player and singer.

Music and dance are clearly part of the stereotype of the black character (see the "Mourisca Retorta," the Auto da Natural Invenção, and the Auto de Vicenteanes Joeira). Insinuations of disorderly sexual desire are also present. Black characters are associated with drunkenness (in Henrique da Mota's dialogue known as "Pranto do Clérigo," in the Prática de Oito Figuras, and in Gil Vicente's Maria Parda where, without use of denigrating language, a mulatto woman complains about the lack of wine in Lisbon). Laziness, deceit, and inclination to theft are the attributes of the black character in Clérigo da Beira. Association with theft is particularly common, also being present in Frágua d'Amor, Prática dos compadres, Prática de Oito Figuras, and Sebastião Pires's Auto da Bela Menina (before 1591).

This association with moral vices is often operated through metaphor. In the Auto da Bela Menina the black character evokes "Santa Ladra" ("Saint Robber"), thus creating an immediate identification between himself and the act of stealing. In Frágua d'Amor the same process occurs: when the black character enters, "singing in the language of his country" ("cantando na língua de sua terra"), Venus asks him what news he brings from Castile. By answering that grapes are mature and that he has harvested them all, he confirms the expected association between the black character and drunkenness. To these recurring associations can be added a long list of insults, downgrading black characters to the category of animals: dogs, bitches (perro, perra), but also dolphins, foxes, 
and dark birds ("night-jars"). Association with the devil or witchcraft is also present, as well as with clowns (Frágua d'Amor).

Anthroponymy and toponymy were also highly stereotyped. From six Portuguese plays where black male characters have a name, four of them are called Fernando and one of the female characters - who is in fact a white male judge disguised as a black servant-is called Catarina Fernando. The fortune of Fernando as a first name of black characters comes from Vicente's autos, starting from Frágua d'Amor (1524); we can see the association at work in a single line of António Prestes's Auto dos Cantarinhos, which invokes the lies of a "Frunando," otherwise absent from the play ${ }^{24}$ One important thing to note about the repeated use of this particular name is the fact it had an expressive mockery value in relation to phonetic deformation attributed to black characters' speech: the difficulty of pronouncing consonant groups such as $r n, r t$, or $r g$ would force the use of a $u$ as a supporting vowel between (and sometimes also before) consonants. Fernando would be then pronounced as "Frunando" or "Furunando." This can be read as evidence of the fact that linguistic distortion for comic purposes prevailed over any "realistic" representation of black people's names. The same applies to the reference of toponyms of African origin: apparently precise (Sierra Leone, Manicongo, Benin, Guinea), they are repeated from play to play, with the primary function of characterization.

Stereotyping was not, as I said before, exclusive to black characters. The whole of theatrical production of this period was, in a sense, based upon stereotypes-allowing for the immediate identification of social characters. In fact, the audience's expectations depended on their production and reproduction. In the autos of Gil Vicente, the lack of individuation is common, with characters more often identified by their social status than by a particular biography. They are "figures" that correspond for the most part to social types (or to allegorical ones) representing status, particular crafts, and local identities. This was even more the case in interludes, either within a larger auto or presented autonomously, where minor characters featured for comic purposes. Such strong bonds between dramatic characters and social identity were underlined by the persistence of certain psychological features and, often, of a first name. Thus, if Fernando is typically the black character, in Vicente's plays-and in many other texts - the simple-minded was called Joane; the ignorant peasant, Gonçalo.

In this context, it may be reasonable to establish a parallel between the stereotyped features of the characters in Portuguese autos and the engravings 
that represented them in the printed editions of the plays. If we take the example of nineteen theatre pamphlets published by Carolina Michaëlis in 1922, we find a systematic reuse of the same engravings. From sixteen original engravings, rearranged for each edition, 48 different images were produced. The same engravings were reused to represent different characters, at times allowing for quite risky identifications. For the purpose of this article, the most interesting example of such a circulation is a set of engravings in two known editions of the Auto das Regateiras, by Chiado. Both pamphlets use the same image of two ladies in profile-one ahead, lifting her gaze up, the other one behind, more ecstatic, holding the tail of her dress. In the edition conserved at the National Library of Lisbon, this second figure has a black face. This means that in one case the engraving was painted black in order to represent the character of the slave Luzia. ${ }^{25}$ The result, involuntary as it might have been, is the social promotion of Luzia, dressed well-above her status.

\section{Language as a second skin}

In order to examine the specific role of language in the construction of the black character, I will begin by describing a scene from Vicente's play Frágua d'Amor, billed as a "tragicomedy" in the Copilaçam de todas as obras ${ }^{26}$ and represented in Évora in 1525 on the occasion of the marriage-celebrated in the bride's absence-between King João III and Queen Catarina of Austria, sister of Charles V. The forge (frágua) that gives the play its title is the working hearth of four blacksmiths, Mercury, Jupiter, Saturn, and the Sun, acting under the direction of Cupid. As a concrete manifestation of the transmutations taking place in Portugal under the sign of the new love between Portugal and Castile, Cupid's forge offers the chance to metamorphose the physical condition of any person willing to do so, man or woman, big or small, fat, old, black or of mixed race (parda). The first person to enter the forge is a black man who, in an earlier scene, had already engaged in a dialogue with Venus, mother of Cupid, and tried to seduce her. This dialogue conveys a series of self-denigrating stereotypes and metonymies: entering the stage "singing in the language of his homeland" ("cantando na língua de sua terra"), he is shown to be an inveterate drunkard and a thief and, most of all, reveals the ridiculous pretension to love Venus, goddess of Love and model of beauty. In the following scene, he goes 
to the forge and states his pretension to be turned white "as a chicken egg" ("branco como ovo de galinha"), with his nose "well done," "very thin" ("minha nariz feito bem," "nariz mui delgada"), his "lips thin" ("beiça delgada") and his "fingers pretty" ("fermosa minha dedo"). To begin the work of the forge with a black person provokes astonishment from Jupiter. Yet the black man enters the machine. After the work of the hammers, he comes out as a "very gentle white man," but his deformed way of speaking Portuguese remains the same (as the stage direction goes, "Sai o Negro da frágua muito gentil homem branco, porém a fala de negro nam se lhe pode tirar na frágua"). The black (now white) man emphatically complains and asks to be given his original skin colour again, realizing that changes in colour are useless if they aren't accompanied by a parallel metamorphosis in speech.

The comical situation consists here of an inversion of what is available to change in nature and in society: by the alchemical power of the forge, the metamorphosis of physical characteristics, unavailable in the natural order, becomes possible. By contrast, language, which is a human and social feature and is therefore susceptible to change, takes the place of the black physical character and becomes a congenital feature that not even the miraculous power of supernatural entities can whiten. This situation corresponds to the comical reversal of classical proverbs and anecdotes that insisted on the impossibility of whitening a black person. With ancient origins, going back to Aesop's fables, one such proverb was compiled in Alciato's Book of Emblems, published for the first time in Latin in 1531 and widely diffused in sixteenth- and seventeenthcentury Europe. Emblem 59 represents the "impossible": a wooden engraving shows two men washing a black figure, with a legend saying: "Why do you wash, in vain, the Ethiopian? Oh forebear: no one can brighten the darkness of black night." ${ }^{27}$

The scene of the Frágua d'Amor can work as a metaphor of the way the denigrating language works in the texts considered here. It is as if the speech stuck to the black figure, as a second skin and second nature, denoting as much as colour. We can speak of an almost phenotypical language that immediately indicates the presence of a black figure, regardless of its physical appearance on stage, all the more so when one reads it on the page, away from the performance and the bodily representation.

While language sticks to skin, it also functions independently. By an effect of metonymy - where a sign represents the thing itself-speech gains the value 
of comical representation, outside of any concern for realism. ${ }^{28}$ This is what happens in another play by Gil Vicente, the last known of his career, Floresta de Enganos (A Forest of Errors), also represented in Évora before the court of João III in $1536 .{ }^{29}$ It is a farce with an allegorical subject, the never-ending succession of errors and deceits between humans and also between gods. Characters continuously deceive each other, creating a comical chain of involuntary consequences. In one of the situations, a chief justice ("doutor justiça Maior do Reino"), old and married, tries to seduce a maiden who works as a household servant. She pretends to give in and asks him to visit her secretly at night. As the judge arrives, the girl persuades him to take off his magistrate's garments and to disguise as a servant so that the old landlady does not notice him. It's in this humiliating position, sifting flour, that he is found by the old woman. Before being fully disclosed as a "doctor under a napkin of a baker-woman" ("doutor em fraldas de panadeira"), he is rebuked and insulted as a "small bitch"-or cadelinha, a then-current insult applied to black women-by the old woman. Fully assuming his disguise, the judge changes his prestigious Spanish into a Spanish-based denigrating language intermingled with Portuguese:

\author{
Why, milady, [are] you \\ so much in a temper? \\ Everything [is] sifted now \\ why [do you] yell at me now \\ what [are] you saying? \\ Me called Caterina Furnando \\ Never me not a bitch ${ }^{30}$
}

Unmasked in front of all, the judge's status is strongly discredited. As he strips off his judge's clothes and assumes the servant's, he is triply deprived of social dignity-by becoming a woman, a servant, and a black person. Language works here essentially as a sign. The judge becomes a black servant from the moment he's persuaded to don that disguise. This disguise is merely a mask, not accompanied by any realistic characterization. The servant's garments and the adoption of her way of speaking work merely as exterior signifying elements, contributing to the judge's change of status. The judge's apparently spontaneous knowledge of a black servant's manner of speaking, which could be interpreted as a sign of the speech's widespread diffusion, seems to reveal on the contrary, 
once again, the artificial origin of the language. It is the stereotypical status, easy to recycle, that makes it so easy to identify and reproduce.

Other sixteenth-century Portuguese plays also reveal a use of language, attributed to black people, as pure sign, no longer requiring a present object. In the plays of Chiado, for example, white characters spontaneously speak parodic black language in a variety of situations. In the Prática de Compadres, although there are no black characters in the play, linguistic distortion occurs in an argument between husband and wife. To inform her husband that his cape had been stolen from the house, the woman imitates "guinean" language: "do you want me to speak Guinean? / Your cape already was / taken by a thief" ("Quereis que vos fale Guiné? / Capa de vossa mercê / já levou ele ladrão," v. 98-101). A few lines below, in order to dissuade the husband from shouting at her, she advises him to find a slave he can shout at. Here we find the common association between black people and theft and slavery. As usual, linguistic deformation to characterize the speech is associated with the conveyance of moral and social stereotypes. More interesting are two other brief examples from Chiado's plays. In the Auto das Regateiras, the character Pero Vaz addresses himself to a black servant, Luzia, who was included as part of the dowry in his son's wedding. He speaks to her in what he supposes to be fala de negra. This causes the astonishment of Luzia's mistress, the old woman: "she is not that wild / speak to her in your own language" ("Não é ela tão salvagem / falai-lhe vossa linguagem," v. 810-11). In the aforementioned scene of the Auto da Natural Invenção in which a landlord mistakes a black musician for a slave and threatens him with corporal punishment, the irony of the situation is underlined by the fact that the talented black musician also speaks "correct" Portuguese. The white landlord completes the ironic reversal by using words and verbal forms from denigrating language (v. 210-12). In both plays, then, we find black characters who speak correct Portuguese and are thus apparently dissociated from the linguistic incompetence stereotype. These are important examples-proof that authors could represent black characters without a self-denigrating language. Nevertheless, in both plays, the black character's use of "correct" speech visibly upsets the white characters' expectations (which we can read as standing for the audience's expectations). In both plays, the white character takes on the "black" speech as if to underline the comic reversal.

In these two examples, denigrating language works like a metaphor or metonym, ready for use on different theatrical occasions. Rather than simply 
play a black character, white actors speak for a brief moment in a language that has the signifying power of invoking a moral character. By doing so, they are being doubly parodic: they are parodying a parodic language.

\section{Masks and metonymy}

Spanish theatre, and in particular some interludes (entremeses), also explores the comic aspect of putting denigrating language in a white character's mouth. The parody of a parody is present here too: not only do white actors disguise as black, but they also represent themselves using "black people's language" as an autonomous signifying comic feature. Sometimes the use of masks is mentioned. For instance, in the entremés called Los negros de Santo Tomé, a band of thieves, in order to escape justice, pretends it is a group of black people rehearsing a danza de negros. They put on black masks (máscaras de negros), caps, and small drums (tamborilillos). Interrogated by a sheriff (alguacil), they answer by singing a song that purposely throws the question from one to the other, until the sheriff gives up and concludes he is before black bozales who don't understand his language. Thinking they are ignorant, he fails to appreciate his own ignorance and ends up being deceived himself.

The very important question of how black characters were made up on stage also deserves our attention. In this article, we are dealing with theatrical texts essentially as a literary source; the dimensions of actual presence and performance, fundamental to the reconstitution of meaning, remain hidden behind the surface of the text. This is why it is relevant to reconstitute, albeit from scarce sources, the concrete aspects of the social identity of actors and performers, and also the way black identity was materially represented on stage. According to Fra Molinero, in Spanish theatre the current practice was to paint the hands and faces of white actors black. ${ }^{31}$ The interlude Los Negros de Santo Tomé gives us an example of another form of make-up: the use of masks, allowing for a quick disguise in the middle of a representation.

Wearing tight dresses representing dark flesh was still another possibility. The object of the Jesuit play Tragicomédia de la Conquista del Oriente, presented in 1619 in Lisbon by the students of a Jesuit college for King Philip II (III of Spain) and his son and heir, the future Philip III, were the feats of the Portuguese in Asia in the golden era of King Manuel ${ }^{32}{ }^{32}$ At one point, a 
personified Brazil (which had just been discovered) enters the scene. He is accompanied by an Indian king (a "tapuya") and by a court of Indians, parrots, and monkeys. Brazil was dressed up with a "black body stocking" ("un vestido justo de color de negra carne"). The other Indians were dressed up the same way, "simulating nudity" ("vestido justo, y de pardo que fingia desnudez"). As for the king tapuya, he was a "naturally dark-skinned" student of philosophy and canon law. ${ }^{33}$ To pay a tribute to the European king, the Amerindian asks for a guitar and plays from the bottom to the top, like a "rude and bozal." The song that he sings to the king, along with the group of Indians, is not in any Amerindian language but in fala de negro. It acts, with no pretension to realism whatsoever, as a stereotyped sign of exotic difference.

Such examples seem to show a paradoxical flexibility in the characterization of black figures on stage. Like the engravings representing white women that could easily be painted over to represent a black one, the use of language as a mere sign or a mask to signify black characters was easily available and ready for use. There seems to have existed a paradoxical combination between the great rigidity of stereotypes and the lightness of their use on stage. Rigidity in the characterization of social characters, often reduced to signs and superficial masks, went along with the easiness with which "higher" social identities could be occasionally mocked by signifying elements attributed to "lower" ones.

In other words, language could be used against white authorities, as in the example of the chief justice in Floresta de Enganos, or simply as an instrument of comic deceit of the same authorities, as in the case of the Spanish interlude Los Negros de Santo Tomé. In both cases, stereotyped language was a metaphoric resource-and at times an instrument of symbolic inversion of the social order, to be represented in the theatre.

Such an inversion was comical, but it could also carry a more serious criticism of the social order. "By having the wrong character pronounce the right judgement," ${ }^{34}$ the black character, although stereotyped, could become a symptom of social disquiet or an instrument of (albeit localized) moral criticism. Several examples may be extracted from the plays, beginning with Henrique da Mota's dialogue, where a woman slave is accused by a clergyman of having spilled a barrel of wine. ${ }^{35}$ She defends herself in a persuasive way and turns the initial accusation into an insinuation of abuse against her by the clergyman. In Chiado's autos, the spectator and the reader are invited to compare the iniquitous, violent relations in familiar households to the institution of slavery 
(the old woman in the Auto das Regateiras, the wife, Brázia, in the Prática dos Compadres). Black servitude is thus, sometimes explicitly, a symptom of servitude within white society. ${ }^{36}$

The black character in Vicente's Clérigo da Beira provides us with a captivating praise of laziness. As Paul Teyssier wrote, it is the most developed and characterized figure in Vicente's plays. Clérigo da Beira is a farsa de folgar, presented to the court of King João III in Almeirim in 1526. It stages a clergyman of doubtful vocation and morality, coming from the region of Beira, in the interior of Portugal-a region to which were attributed most of the rural negative stereotypes in Vicente's plays. In the middle of the play, there is the story of an ignorant peasant, Gonçalo, who gets successively robbed, first by two valets from the court and then by a "Black big thief" ("Negro grande ladrão"). The latter declares his solidarity with Gonçalo's misfortune and claims to be absolutely incapable of stealing. He then lures Gonçalo into trusting him by a sophisticated theory of moral (in)action: there is no point in stealing, not because of particular ethical reasons, but because life is so tiresome for everyone, from the humblest slave to the Pope in Rome. What is the point in stealing, then?

What for? To eat?

Much eat[ing], much drink[ing]

everything [is] tiresome

Says [I will say]: the whole world [is] tiresome

Big master tiresome

Poor man tiresome

beautiful woman tiresome

ugly woman tiresome

black slave tiresome

master of slave tiresome

go [to] mass tiresome

long prayer tiresome

priest [who] has no woman tiresome

priest [who] has woman very tiresome

loose gentleman tiresome

much rain tiresome

[when it] doesn't rain tiresome

many child[ren] tiresome 
never give birth tiresome

Pope in the Rome tiresome

this peasant tiresome

we don't go [to] paradise very very

very tiresome

Life in this whole world [and] everything is tiresome

Me don't speak mockery

Why rob then?

if the devil is always [around]

opens his eye everyday ${ }^{37}$

The skilful combination of a variety of social frustrations and the repetition of the "tiresome" refrain invite us to adopt for a moment the black thief's point of view. In the end, in the face of the fatigues of the world isn't inaction the wiser attitude? Stereotype is fully represented in this scene, it is never denied (a black thief prone to laziness). To be sure, it is impossible to project oneself on to Gil Vicente's spectator in order to measure the degree of possible identification with Fernando's ethics. But it still offers to today's reader the whole power of his suggestion of an alternative ethics.

Another interesting example of this phenomenon is to be found in the Entremés de los negros, by Simon Aguado, dated from 1602. This interlude shows us how the love story of two slaves, Gaspar and Dominga, is seen as an inconvenience to their respective masters, as their successive amorous meetings trouble their work duties. The masters first try to separate the two lovers, but in the end give up - thanks to the wise mediation of one of the master's wives-and accept the slaves' requests to date each other. The logic of the appeal, coming from the slaves' mouths, is impeccable and based upon Christian principles of justice. When her master, Ruiz, threatens her with physical punishment if she speaks to Gaspar again, Dominga appeals to books and laws: "Tell me, master, in which book have we read that a poor black woman, although she is a slave of Pontius Pilate, cannot fall in love? Is there any law that says that black man and woman cannot make black child when we finish [to] bed down our master?"38

The predictable solution to this conflict is Christian marriage and regulation of the disorderly black couple's sexuality. Gaspar and Dominga are eventually allowed to sleep together on Saturdays only. This condition opens the door to mockery: Gaspar asks his master how many Saturdays there are in each week. 
Confronted with the frustrating answer of his master, he does not abandon his intention and affirms that for him Saturday is every day of the week. This same story, with one small variation, is present in the already quoted Entremés de los Mirones. ${ }^{39}$ It was probably a well-known anecdote which playwrights could integrate, almost without change, in their own plays.

Further examples of this kind of transaction between anecdotes and the stage or the printed text exist in later Portuguese sources. For instance, the anecdote of the black servant who had the pretension of seeing herself in the mirror of her mistress is present in the Folheto de Ambas Lisboas, printed in Lisbon in 1730-31, a satirical periodical where we find more examples of fala de negro. The anecdote was also the subject of burlesque (jocosérios) sonnets in different pamphlets and books of the same period.

\section{Conclusion}

The repetition of denigrating stereotypes from play to play was not simply a popular dramatic resource. It corresponded to a circulation of themes and images that existed offstage, in different media and social contexts, renovated across time and forming chains of anecdotes for literary and social purposes. A final, and in my view very significant, example of such a circulation-in handwritten copies-can be found in the satirical dispute between António Ribeiro Chiado and Afonso Álvares, the latter of whom is presented in surviving manuscripts as a "mulatto" and a "poet." ${ }^{40}$ Confronted with Álvares's criticism of his immoral behaviour regarding the Franciscan order, from which Chiado had earlier escaped, the latter replies with a flow of racial resentment, using pretty much the same metonymic insults that he used in his plays-Auto da Natural Invenção or Auto das Regateiras_-associating Álvares with animals, darkness, filth, theft, the devil, or slavery. The two men engage in a polemic in rhyme without the protection (however light) of comic masks. It is no coincidence that in the third stanza of his first reply to Álvares, he addresses his rival in denigrating language. Chiado wanted to make clear from the start, to other readers of his verses, the condition with which he associated Álvares.

I started this article with methodological reservations about the use of the language attributed to black Africans in dramatic texts-as a legitimate source for the study of their spoken language. By doing so, I intend to put into 
question the transparent link between the literary source and the social world, or, to say it in other words, between stereotype and its wider history. It may be appropriate to conclude by reintroducing such a link. Authors of comedy drew on anecdotes that circulated in non-literary texts; on the other hand, they reintroduced and amplified such stereotypes in the social world. Stereotypes promote-sometimes violently-a reduction of the complexity of social life. But they have themselves a textual and material history that can, to a certain extent, be traced.

\section{Notes}

* I am indebted to Catarina Madeira Santos and Jean Hébrard, who first gave me the opportunity to present and discuss earlier parts of this research in their seminar "Les sources documentaires de l'histoire du fait colonial" at the École de Hautes Études en Sciences Sociales, Paris, June 2009. I am also grateful to one anonymous reader of Renaissance and Reformation/Renaissance et Réforme for remarks on a first version of this article, calling my attention to potential ambiguities in it, which I have since tried to clarify. Any remaining inconsistencies are, of course, my responsibility.

1. See José Ramos Tinhorão, Os Negros em Portugal. Uma presença silenciosa (Lisboa: Caminho, 1988) for more information and for a useful list of sources at the end of the book.

2. See K. J. P. Lowe, “The Stereotyping of Black Africans in Renaissance Europe," in Black Africans in Renaissance Europe, ed. T. F. Earle and K. J. P. Lowe (Cambridge: Cambridge University Press, 2005), pp. 17-47; other contributions to this book are also quite useful. See K. J. P. Lowe, ed., "Sub-Saharan Africa and Renaissance and Reformation Europe: New Findings and New Perspectives," special issue, Renaissance and Reformation/Renaissance et Réforme 31, no. 2 (2008). For a rich and global analysis of the image of black characters in Spanish theatre, to which I am indebted here, see Baltasar Fra Molinero, La imagen de los negros en el teatro del Siglo de Oro (Madrid: Siglo XXI, 1995).

3. Aurelia Martin Casares, "Popular Literary Depictions of Black African Weddings in Early Modern Spain," in Lowe, Renaissance and Reformation, pp. 107-121, especially pp. 107-09. 
4. On the formation of this ideology, see Cláudia Castelo, "O modo português de estar no mundo." O luso-tropicalismo e a ideologia colonial portuguesa (1933-1961) (Lisbon: Afrontamento, 1998).

5. Entremés de los Mirones, in Emilio Cotarelo y Mori, Colección de Entremeses. Loas, bailes, jácaras y mojigangas, ed. facsímil, J. L. Suárez y A. Madroñal (Granada, Universidad de Granada, 2000), vol. 1, "Entremeses Anonimos," 42, p. 162 (my own translation). The original text follows:

"se fue [un estudiante] disimuladamente arrimando adonde vía que estaban algunos en buena conversación, y oyó que, al cabo de muchos cumplimientos que pasaron entre unos cuantos negros (porque ellos son, no sólamente con los blancos, sino consigo mismos, cortesísimos y llenos de ceremonias), preguntó uno con su media lengua a otro: 'Vuesa merced me diga, ¿ es verdad que su amo le ha vendido?'. - 'Sí, señor, vendido me ha,' dijo el otro. - ‘En cuanto, por mi vida, vendió a vuestra merced?'. - 'En ciento y veinte ducados.' El otro, cabeceando, y mirándole desde los pies a la cabeza, dijo con grand ponderación: - 'Mucho es; por vida mía! No vale tanto vuestra merced, ni con buen cato: ochenta ducados vale vuestra merced, y no una blanca más."”

6. E. de Chasca, "The Phonology of the Speech of the Negroes in Early Spanish Drama," Hispanic Review 14, no. 4 (1946), pp. 322-39; P. Teyssier, La Langue de Gil Vicente (Paris: Klincksieck, 1959), pp. 227-50; C. B. Letuario, "Las hablas de negros. Orígenes de un personage literario," Revista de Filología Española 69 (1989), pp. 311-33; J. M. Lipski, "Afro-Portuguese Pidgin: Separating Innovation from Imitation," a paper presented at the annual meeting of the AATSP, Philadelphia, 1994, accessed October 26, 2012, http://www.personal.psu.edu/jml34/afrop.pdf.

7. The argument is presented in Lipski, p. 5.

8. Teyssier, p. 248.

9. In the same sense, see Luciana Stegagno Picchio, Ricerche sul Teatro Portoghese (Rome: Edizioni del Ateneo, 1969) pp. 24-26, with references to the stylistic rather than linguistic use of sayagués, the language attributed to peasants in sixteenthcentury Spanish theatre.

10. See Carolina Michaëlis de Vasconcelos, "Contribuições para o futuro dicionário etimológico das línguas hispânicas," in Revista Lusitana (Lisboa: Imprensa Nacional, 1908), vol. 11, p. 15.

11. Queree / quere and furutaa / furtaa. See Obras completas de Gil Vicente, ed. José Camões (Lisbon: Imprensa Nacional-Casa da Moeda, 2002) vol. 3, p. 317 and vol. 4, p. 379. 
12. See Ana Hatherly, Poemas em língua de preto dos séculos XVII e XVIII (Lisboa: Quimera, 1990), pp. 15-20.

13. In the original: "Si escribes comedias y eres poeta sabrás guineo en volviendo las rr-ll, y al contrario: como Francisco, Flancico; primo, plimo," in the section called "Para saber todas las ciencias y artes mecánicas y liberales en un dia," in Obras de don Francisco de Quevedo Villegas, Biblioteca de Autores Españoles 23 (Madrid: M. Rivadeneyra, 1852), p. 480.

14. Biblioteca da Ajuda, 49-III-60 and 49-III-64.

15. See the prologue to Cervantes's Ocho comedias y ocho entremeses, ed. Florencio Sevilla Arroyo (Madrid: Castalia, 1999), p. 877.

16. According to Fra Molinero, pp. 19 and 24n10. See also Letuario.

17. The primary sources are cited throughout, with this exception: D. Rodrigo de Monsanto and João Fogaça, "A Lourẽço de faria da maneira que mandava a hũ seu escravo q. curasse hũa sua mula" (1490), in Cancioneiro Geral, 1516.

18. Fra Molinero, p. 20, and chapters 3 to 7 of the same book.

19. José da Silva Terra, “A datação do primeiro texto em 'Língua de Preto’ na literatura portuguesa," offprint of Diacrítica 11 (1996), pp. 513-27.

20. Garcia de Resende, Chronica de D. João II e Miscelânea (Lisbon: Imprensa Nacional-Casa da Moeda, 1991), p. 150-52. The same information is present in the Obras inéditas de Aires Teles de Meneses e de Estevão Rodrigues de Castro (Lisboa, 1792), p. 121. These documents were recently republished online in the University of Lisbon's Centro de Estudos de Teatro's historical database, accessed October 26, 2012, http://www.fl.ul.pt/cethtp/webinterface/default.htm.

21. See Silva Terra, pp. 520-21.

22. See Resende, pp. 173-75. My own translation; the original text follows: "E ouue ali hũa muyto grande representaçam de hum Rey de Guine, em que vinham tres Gigantes espantosos, que pareciam viuos, de mais de quarenta palmos cada hum, com ricos vestidos todos pintados douro, que parecia cousa muyto rica, e com elles hũa muy grande, e rica mourisca retorta, em que vinham duzentos homens tintos de negro, muyto grandes bailadores, todos cheos de grossas manilhas pollos braços, e pernas dourados, e muyto bem concertados, cousa muy bem feyta, e de muyto custo por serem tantos, e em que se gastou muyta seda, e ouro, e faziam tamanho roido com os muytos cascaveis que traziam, que se não ouuiam com eles...."

23. Fernão da Silveira, "Por breue de hũa mourisca rratorta, que mandou fazer a senhora prinçesa quando esposou" (1490). The translation is my own and seeks to 
maintain some fidelity to grammatical faults. See Cancioneiro Geral de Garcia de Resende, ed. Andrée Crabbé Rocha (Lisbon: Centro do Livro Brasileiro, 1973), vol. 1, pp. 204-05. The original text follows:

A min rrey de negro estar serra Lyoa

lonje muyto terra onde viver nos,

lodar caytbela tubao de Lixboa

falar muao nouas casar pera vos.

Querer a mym logo ver vos como vay,

leyxar molher meu partyr muyto sinha,

porque sempre nos seruyr vosso pay,

folgar muyto negro estar vos rraynha.

Aqueste gente meu taybo terra nossa

nunca folguar, andar sempre guerra,

nam saber quy que balhar terra vossa,

balhar que saber como nossa terra

Se logo vos quer mandar a mym venha

fazer que saber tomar que achar,

Mandar fazer taybo lugardes mantenha

\& loguo meu negro senhora balhar.

24. Autos de António Prestes, ed. José Camões and Helena Reis Silva (Lisbon: INCM, 2008), p. 514, 11. 944-45.

25. The two engravings of the Auto das Regateiras are the property of the National Library of Madrid and the National Library of Lisbon. The same engraving of the two ladies, both white, is present in a copy of the Auto das Capelas (anonymous author). See Teatro de António Ribeiro Chiado, ed. Cleonice Berardinelli and Ronaldo Menegaz (Porto: Lello e Irmão, 1994), p. 101, n. 1.

26. Camões, Obras completas de Gil Vicente, vol. 1, p. 641.

27. "Abluis Aethiopem quid frustra? Ah desine: noctis Illustrare nigrae nemo potest tenebras," from Alciato's Book of Emblems: The Memorial Web Edition in Latin and English (2005), accessed October 26, 2012, http://www.mun.ca/alciato/059.html.

28. See Fra Molinero, p. 25.

29. Camões, Obras completas de Gil Vicente, vol. 1, p. 479.

30. Camões, Obras completas de Gil Vicente, vol. 1. The original text from Gil Vicente's Floresta de Enganos: 
Por qué vos mia señora

estar tanto destemplado?

Ya tudo estar peneirada

que bradar comigo ahora

que cousa estar vós hablanda?

A mi llama Caterina Furnando

nunca a mi cadella não. (II. 642-48)

31. Fra Molinero, p. 20.

32. What we know from the play does not come from an original text, but from the extended, multilingual description of the play made by João Sardinha Mimoso in the volume Relacion de la Real Tragicomedia con que los Padres de la Compañia de Iesus en su Colegio de S. Anton de Lisboa recebieron a la Magestad Catolica... (Lisbon: Jorge Rodrigues, 1620).

33. “...era de su natural pardo, y sobre manera agraciado, que de muy lexos nose pudiera hallar mas pintado a lo que pedia la obra y el lugar; estudiante ansi mismo, Philosopho y Canonista," in Mimoso, p. 57.

34. Constantine Christopher Stathatos, A Critical Edition with Introduction and Notes of Gil Vicente's Floresta de Enganos (Chapel Hill: University of North Carolina Press, 1972), p. 27.

35. Henrique da Mota, "A hũ creligo sobre huũa pipa de vynho q. se lhe foy polo chã, \& lemẽntaua o desta maneyra," in Cancioneiro Geral (1516), vol. 5.

36. In Brázia’s words: "Have your own slave / and yell at no one" ("Havei ũa escrava de vosso / e não bradeis com ninguém”), in António Ribeiro Chiado, Prática dos Compadres (before 1572), ll. 103-04.

37. Gil Vicente, Clérigo da Beira (1526 or 1529/30), II. 484-512. The original text:

Para quê? Para comê?

Muto comê, muto bevê,

turo, turo sa canseyra

dirá mundo turo canseyra

senhor grande canseyra

home prove canseyra

muyere fermoso canseira

muyere feo canseyra

negro cativo canseyra

senhoro de negro canseyra

vay misa canseyra 
pregaçam longo canseyra

crérigo nam tem muyere canseira

crérigo tem muyere grande canseyra

firalgo solto canseyra

chovere muyto canseyra

nam podê chovere canseyra

muyto filho canseyra

nunca pariro canseyra

Papa na Roma canseyra

essa ratinho canseyra

nam vamo paraíso grande grande

grande canseira

Vira resa mundo turo turo hé canseyra!

Mi nam falá zombaria

Pos para que furtá?

que riabo sempre sá

abre hoyo turo ria.

38. "Pues señolo de mi entrana, en qué libro habemus leiro que una pobre negra, aunque sea crava de Poncio Pilato, no se pora namorar? Hay alguna premática que diga que negro con negra no poramo hace negriyo cuando acabamo de acosar á nuesamo?” from Simon Aguado, Entremés de los negros (1602), in Emilio Cotarelo y Mori, Colección de Entremeses. Loas, bailes, jácaras y mojigangas, ed. facsímil, J. L. Suárez y A. Madroñal (Granada: Universidad de Granada, 2000), vol. 1, "Entremeses de Varios Autores," 60, p. 232.

39. Entremés de los Mirones, p. 163.

40. On Afonso Álvares, who was possibly also a writer of saint's plays, see the introduction of José Camões to the edition of Álvares's plays: Obras de Afonso Álvares (Lisbon: Imprensa Nacional-Casa da Moeda, 2006), pp. 7-13. Also T. F. Earle, "Black Africans Versus Jews: Religious and Racial Tension in a Portuguese Saint's Play," in Earle and Lowe, eds., pp. 345-60. 